\section{Noticias y comentarios}
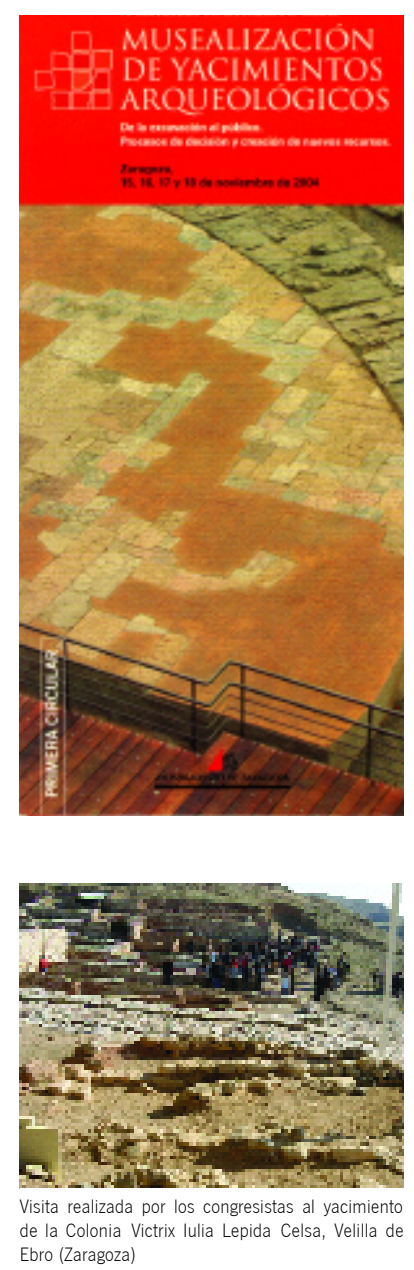

\title{
Musealización de yacimientos arqueológicos: cómo llegar de la excavación al público
}

Entre los dias 15 y 18 de noviembre de 2004 se celebró en Zaragoza el III Congreso Internacional sobre Musealización de Yacimientos Arqueológicos, con la asistencia de 409 inscritos procedentes no sólo del territorio español, sino de diversos países europeos, entre los que destaca Portugal por el número de participantes. El título escogido en esta ocasión fue De la excavación al público. Procesos de decisión y creación de nuevos recursos.

La primera ponencia, con el título de "Excavar, Exponer, Conservar o Reservar. Criterios técnicos para un proceso de decisión", fue desarrollada por Antoni Nicolau y de ella se dedujo que:

$>$ Es necesario avanzar en una metodología de análisis y evaluación de los restos arqueológicos exhumados para decidir respecto a su conservación; crear instrumentos de inventario del patrimonio arqueológico; crear áreas de reserva arqueológica; integrar el patrimonio arqueológico en el planeamiento; y avanzar hacia un verdadero trabajo interdisciplinar.

$>$ No todo lo que se decida conservar debe convertirse en un museo. Se deben ensayar fórmulas de conservación, integrando los restos en nuevos proyectos arquitectónicos de usos alternativos.

$>$ Debe impulsarse la discusión en torno a la creación de una metodología de análisis, basada en indicadores de evaluación a partir de la propuesta formulada por el ponente. Se abrirá un foro de discusión y no se descarta la realización de alguna reunión monográfica al respecto.

> Parece importante destacar, como propuesta concreta, la creación de otro foro de discusión relacionado con la necesidad de precisar los conceptos y la nomenclatura de los dispositivos de musealización del Patrimonio: Yacimiento musealizado, Museo, Museo de sitio, Centro de interpretación, etc.

"De la conservación a la presentación. El tratamiento de los restos: Reintegrar, Reconstruir, Recrear...", a cargo de Manuel Olcina, estableció estas reflexiones:

> Debe buscarse la máxima legibilidad de los vestigios por ellos mismos, añadiendo los elementos claves y ciertos que ayuden a su comprensión. Las recreaciones virtuales que se realicen deben incluir esos elementos claves.

$>$ Al aplicar operaciones como restauración o reintegración es importante no vulnerar la integridad de los restos.
$>$ Los antiguos habitantes de los yacimientos que musealizamos son los protagonistas de la historia, son lo intangible. Es necesario ambientar el espacio de su vida, teniendo en cuenta que ese espacio in situ debe estar bien presentado y ser comprensible.

En la tercera ponencia -"Explicar o contar. La selección temática del discurso histórico"- José Antonio Lasheras alcanzó las siguientes conclusiones:

$>$ Un yacimiento musealizado es la exposición de sí mismo, concebida con criterios de divulgación y destinada, obviamente, a un público "no conocedor".

$>$ La selección de los contenidos en un discurso es siempre imprescindible sea cual sea el destinatario, y con más razón en el discurso divulgativo, donde la selección e integración de conocimientos debe producir una información asequible.

Finalmente, Renée Sivan, en "Los yacimientos musealizados como recurso cultural y turístico. Sostenibilidad y calidad de la visita" expuso que:

$>$ El dinero que pasa por nuestras manos es dinero público, y por lo tanto nuestra labor debe ser para el público.

$>$ En todo proyecto el protagonista debe ser el visitante, al que debemos el mayor respeto. Éste se plasma tanto en el contenido y la inteligencia del discurso como en la forma y la calidad de la presentación.

> No basta excavar, no basta conservar, no basta contar, si ante todo no nos cuestionamos para qué lo hacemos, qué queremos decir y para quién.

$>$ En este momento se está invirtiendo una gran cantidad de dinero procedente de financiaciones europeas en proyectos de musealización ¿Qué pasará cuando se acabe? Pensemos, ¿vamos a depender de los vaivenes políticos para su mantenimiento? Creemos entidades que tengan la capacidad de sostener lo creado...

Carmen Aguarod Otal

Jefa de la Unidad de Museos y Exposiciones

Ayuntamiento de Zaragoza 